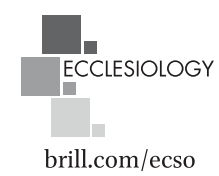

\title{
Editorial
}

\section{Ethics and the Church: A Roman Catholic-Anglican Encounter}

This special issue brings together leading Roman Catholic and Anglican contributors to consider the relationship between ecclesiology and ethics in ecumenical context. Several large issues are explored. One is the nature of ethics. Is ethics codifiable into a set of moral propositions that should be followed, or is it a less tangible collection of principles that may shape personal identity, including in pastoral contexts, and help a church community build cohesion? Another issue is the continuity of ethics through time. Do ethical principles and propositions remain forever unchanged, or does what is morally right vary over time? Then there is the question of how Christian ethics relates to state constitutions and law and what happens when the requirements imposed by each seem to diverge. This problem may be viewed in wider perspective as one dimension of how ethics in the abstract relates to lived ethics. Ethics inevitably has a subjective element because it governs individual behaviour in particular situations. Yet ethical decisions also entail the existence of an objective order of truth. If ethics is simply about behaving as custom dictates, appeasing public opinion or satisfying professional or regulatory requirements, it is not ethics in the true sense of the term.

The debate between absolutism and relativism is not new. Within the Roman Catholic Church, prior to the rise of neo-Thomism during the second half of the nineteenth century, rigorist and formulaic Jansenism, which was grounded in a highly pessimistic theological anthropology, was called into question by the casuistry of the eighteenth-century Italian bishop St Alphonsus Liguori. ${ }^{1}$

1 St. Alphonsus Liguori, Theologia Moralis / Moral Theology, trans. Ryan Grant. 7 vols (Post Falls, ID: Mediatrix, 2017-). 
The Redemptorist founder's moral theology was embraced by many Jesuits. However, it was far from being the licence to act in whatever way one wished in order to achieve desired ends, even though opponents like Pascal presented it as such. Rather, when the morality of an action was in doubt, Alphonsus allowed a position to be adopted that favoured moral freedom, perhaps even when a rigorist interpretation was more probably true. This was consistent with the genuinely Jesuit exercise of the discernment of spirits, laid out in Ignatius of Loyola's Spiritual Exercises, in which the human will is guided in prayerful meditation away from the bad and towards the good.

Because confession was fundamental to lived faith, and was the primary sacrament available in an age of typically infrequent lay communion, moral theology was fundamental to how Christians experienced the Church and its ministry. In the sphere of marital sex, Alphonsus brought a move away from an instrusive Jansenist condemnation of all intentionally unreproductive sex towards a recognition that penitents should not be interrogated on sexual matters. The declining moral absolutism that Peter Sedgwick observes in the Roman Catholic Church today is a repetition of this shift. As Sedgwick himself recognizes, this could be reversed, as previously occurred with the rise and official endorsement of Thomism in the later nineteenth century, which eclipsed the teaching of Alphonsus, and more rapidly with Pope Paul vi's promulgation of the encyclical Humanae Vitae following the realistic engagement with lay concerns at the Second Vatican Council, especially in its closing pastoral constitution Gaudium et Spes of just three years earlier.

Implicated in any opposition to change in moral theology, as well as to the advocacy of change, is some theory of tradition. From the later nineteenth century there has been an increasing tendency, notwithstanding some trenchant resistance, to view tradition as dynamic rather than as static. John Henry Newman presented tradition developmentally, proposing seven criteria to distinguish good and bad developments. ${ }^{2}$ These include the power of assimilation: just as a biological organism takes external materials into itself to create a new unity, so a doctrine or ethical position must be able to absorb views from the surrounding world according to a principle. Yet developments also needed to exhibit what Newman wonderfully terms 'chronic vigour'. Fashions quickly arrive then just as quickly vanish, but faithful change is gradual but tenacious. Shortly after Newman, the French philosopher Maurice Blondel identified the dynamic function of tradition in conserving and transmitting the deposit of

2 John Henry Newman, 'Genuine developments contrasted with corruptions', from An Essay on the Development of Christian Doctrine 1.3 (1878 edn), in Newman the Theologian: A Reader, ed. Ian Ker (Notre Dame, IN: University of Notre Dame Press, 1990), pp. 184-98. 
faith and practice from the past into the present and future. Emphasizing that we cannot step outside of it, he described how tradition, as a result of its own foundation and force, is a vivifying power and an 'experience always in act' that instructs, anticipates and illuminates the future, being 'disposed to do so by the effort which it makes to remain faithful to the past. ${ }^{3}$

Anglican ethical tradition is not codified in a formal body of magisterial teaching. However, from the writings of classic divines such as William Perkins, Richard Hooker, the Caroline divines and Jeremy Taylor, ${ }^{4}$ the documents of the Lambeth Conferences and the lived practice of the Church of England and, more recently, other Anglican Churches, a body of continuing and developing moral teaching, especially regarding method, may be discerned. The deep roots of Anglicanism are found in medieval Christianity in Britain, which, like the Church in many other European states, enjoyed a degree of autonomy from Rome and exhibited its own culture and traditions. Nevertheless, medieval theology, just like the theology of the Protestant Reformation, was pan-European. ${ }^{5}$

The Anglican ethicist Robin Gill narrates his experience teaching the natural law moral theology of St Thomas Aquinas to students of various denominations and none at two British universities, one with a Reformed heritage and the other largely secular. Most students were understandably critical and even shocked by some of the Angelic Doctor's judgments on gender and the raising of children. Given that the Summa theologiae was compiled as a teaching aid and a record of classroom debate, their reaction was entirely appropriate. Indeed, Aquinas might have been more pleased to learn that his theology is sparking debate eight centuries later than that it has been used to present and endorse a supposedly immutable moral code. The Summa theologiae is nothing other than a long series of questions. Each opens with points for and against before the teacher's response setting the matter in order. Points follow clarifying or resolving issues that were raised at the start that might appear as contradictions or complications. For Aquinas, a yes/no question has four possible answers: yes, yes but, no but, or no. The content of his teaching should always be seen in the context of this methodology, which includes the willingness and ability to draw subtle distinctions and qualifications.

3 Maurice Blondel, History and Dogma, trans. Alexander Dru (Grand Rapids, MI: Eerdmans, 1994), p. 268.

4 Peter H. Sedgwick, The Origins of Anglican Moral Theology (Leiden: Brill, 2018); A. J. Joyce, Richard Hooker and Anglican Moral Theology (Oxford: Oxford University Press, 2012).

5 For this reason, if no other, it is ridiculous to compare Brexit with the Protestant Reformation. 
Even more radically, in addition to the Bible, Aquinas made extensive if not uncritical use of pre-Christian philosophers, especially Aristotle, and of Jewish and Muslim thinkers. This aspect of his approach is certainly relevant today, when, as Sedgwick notes, the ecclesial body is characterized by an increased porosity to wider society. This tendency may be problematic in the context of the current shift that he justly identifies away from moral absolutism towards a view of morals as inhering in the life of an ecclesial community. In the twentieth century, for figures like the Roman Catholic lay theologians Jacques and Raïssa Maritain, the ability to reach many varied people who would be unlikely to darken the doors of a church building was grounded in a conservative and rationally-grounded moral system. ${ }^{6}$ When visible boundaries are transgressed or dissolving, there is all the more need for a rule book. A Church may, of course, offer moral leaven to communities around it, but, as in John's Gospel, this requires the church community to have deep spiritual roots and these need sustaining.

Nikolaus Knoepffler and Martin O'Malley discuss a particular ethical debate in Germany that has seen received church teaching come into conflict with state law. A 2020 legal ruling defining a right to self-determination at death has provided legal clarification that third parties may legally assist suicide. This is informed by the country's constitutional Basic Law, which recognizes an individual's freedom to write their own life story. Whereas the Roman Catholic Church, via the Congregation for the Doctrine of the Faith, responded by describing assistance at a suicide as a grave sin, bishops of the Evangelical Church gave more varied assessments. These kinds of conflicts between state law and traditional ecclesial stances are arising more frequently; indeed, the CDF response and its rapidity was partly motivated, as Knoepffler and O'Malley recount, by the prospect of similar developments in Spain and Portugal. In debates such as this, one can often observe two very different views of the nature and function of conscience. The Anglican bishop Joseph Butler and J. H. Newman, in his letter to the Duke of Norfolk, each viewed conscience, in slightly different ways, as governing the person and providing an objective source of moral guidance to inform decisions about how to act. ${ }^{7}$ However, since conscientious objection to conscripted military service in the First World War, conscience has been invoked in a quite different way that emphasizes an

6 Jean-Luc Barré, Jacques and Rä̈ssa Maritain: Beggars for Heaven, trans. Bernard E. Doering (Notre Dame, IN: University of Notre Dame Press, 2005).

7 Joseph Butler, Sermon 2, in id., Five Sermons, ed. Stephen L. Darwall (Indianapolis, IN: Hackett, 1983), pp. 34-41; John Henry Newman, Conscience and Papacy, ed. Stanley L. Jaki (Pinckney, MI: Real View, 2002), pp. 61-74. 
individual's entitlement to make their own moral decisions free from any sense of obligation to public opinion or social custom.

Within theological ethics, ecclesial ethics is currently in the ascendant. Among the Anglican Churches, the work of Stanley Hauerwas, which builds on the neo-Aristotelianism of the philosopher Alasdair McIntyre, has given this intellectual impetus. In the Roman Catholic Church, as Sigrid Müller describes, ecclesial ethics is currently being strongly encouraged by Pope Francis. Müller illuminatingly traces this to Francis's Argentinian Romanticism and theology. In Europe, the twentieth-century experience of fascism and communism still lingers, motivating a theological tendency to regard 'the people' as at ongoing risk of political, moral and spiritual corruption. Francis draws from different streams, in which dignity and development are collective goods that are justly and necessarily striven for by all people and on behalf of all people. His ethics is thus grounded firmly and even primarily in experience and action, with its reception and living out, rather than its objective propositional codification, being the end goal. This vision harmonizes with the fourfold medieval exegesis of Scripture, in which the moral sense existed alongside the eschatological sense, rather than being viewed, as in some modern readings of Scripture, as separable from eschatology and even from doctrine. For Francis, dialogue, encounter and action are the loci of truth.

Müller uses the inverted pyramid model to depict the disruption of classic ecclesial hierarchy that Francis has sponsored. It should be added though that the current Roman Catholic revival of ecclesial ethics is curiously dependent on the theory of papal primacy promulgated at the First Vatican Council. As the apotheosis of Pope Pius IX and the first non-European pope of modern times, Francis has deployed primacy to great effect to connect personally with the hopes, joys and suffering of his Church not just outside of Italy but globally. Communitarian ethicists from Aristotle onwards have needed a father figure to look to for guidance and example. Francis has made himself this figure, providing charismatic challenge to ungenerous conservatism while in no way selling out to secular or theological liberalism.

With his characteristic perspicacity, Oliver O'Donovan contests the oftenheard claim that a wide degree of disagreement on moral matters exists between Churches and that this is the principal reason for difficult ecumenical relationships. So far as official teachings and pronouncements go, he is simply unable to find any significant divergence. It certainly seems, one might add, that there is greater disagreement within most Churches than between them. At a conceptual level, however, O'Donovan queries simplistic understandings of what moral disagreement is. A basic feature of moral action is that it requires both a description and an evaluation of the facts of a situation, and 
then a decision in light of these about how to act. For Aquinas, this is why the virtue of prudence is so important: at once intellectual and practical, it is the capacity to bring general principles to bear on a specific context in a way that produces effective decision and action. Because moral action is, in the way just described, intrinsically contextual, different kinds of action in different contexts do not in themselves amount to disagreement. Disagreement between Churches would need to be at the level of formal teaching, but such teaching, where it exists, is broadly consistent.

\section{David Grumett}

Deputy Editor, Ecclesiology; Senior Lecturer in Theology and Ethics, University of Edinburgh, Edinburgh, UK

david.grumett@ed.ac.uk 